\title{
Climatic Change and the Socioeconomic Sustainability of the Paddy Farmers in Malaysia
}

\author{
Md. Mahmudul Alam* \\ PhD Student \\ Institute for Environment and Development (LESTARI) \\ National University of Malaysia (UKM), Malaysia \\ E-mail: rony000@gmail.com \\ Chamhuri Siwar \\ Emeritus Professor \\ Institute for Environment and Development (LESTARI) \\ National University of Malaysia (UKM), Malaysia \\ E-mail: csiwar@ukm.my \\ Basri Talib \\ Associate Professor \\ Faculty of Economics and Management \\ National University of Malaysia (UKM), Malaysia \\ E-mail: basri@ukm.my \\ Abdul Hamid Jaafar \\ Professor \\ Faculty of Economics and Management \\ National University of Malaysia (UKM), Malaysia \\ E-mail: ahamid@ukm.my \\ *corresponding author
}

Citation Reference:

Alam, M.M., Siwar, C., Talib, B., and Jaafar, A.H. 2013. Climate Change and the Socioeconomic Sustainability of the Paddy Farmers in Malaysia, Natural Science, Vol. 5(1A), pp. 163-166. [Online Link]

This is a pre-publication copy.

The published article is copyrighted by the publisher of the journal. 


\title{
Climatic Change and the Socioeconomic Sustainability of the Paddy Farmers in Malaysia
}

\begin{abstract}
The changing nature of climatic factors has different impacts on agriculture based areas, periods and crops. Farmers are the most vulnerable group who are affected both directly and indirectly through climatic changes. In the study area in Malaysia, climatic changes have adverse impacts on farmers. Due to climatic change, productivity and profitability of paddy cultivation have declined in the Integrated Agricultural Development Area, North-West Selangor. Farmers perceive that paddy cultivation is no longer profitable due to low productivity as a result of climatic changes. They now prefer full-time to part-time engagement in paddy cultivation. Heavy government subsidy and encouragement are not enough; it requires increase in productivity and profitability of paddy cultivation for making it a viable and sustainable sector. All efforts of mitigation and adaptation must be pursued to counter the adverse impacts of climatic changes and increase the productivity of paddy cultivation in the area. It is observed that there is a high degree of income inequality among the paddy farmers in the study area.
\end{abstract}

Key words: Climatic Change; Income Equality, Health Hazard; Agriculture; Paddy; Malaysia

\section{Introduction}

The factors affecting climate are changing all over the world. This phenomenon has multidimensional impacts on human livelihoods. Different groups of people are affected in different ways. Among all the sectors, agriculture is highly dependent on climate variables. Due to the changes in climate factors, the factors relevant to agricultural sustainability such as volume, yield, area, and value of production etc, also change. When the agricultural sustainability is vulnerable, agriculture also varies in several economic factors, such as total production quantity, profit margin of crops, profit margin of final goods, farm and off-farm wage rate etc. As a consequence, the socioeconomic profiles of farm as well as farmers are changing with the changing climate.

Malaysia is one of the vulnerable countries where both agricultural sustainability and related livelihood sustainability are under threat due to the adverse impacts of rapid climatic change. Malaysia ranks as the 26th largest greenhouse gas emitter in the world with a population of about 27 million, and it appears likely to move up the list quickly due to the growth rate of emissions. Here, due to high greenhouse gas emissions, the temperature is projected to rise by $0.3-4.5^{\circ} \mathrm{C}$, which will cause the sea level to rise by about $95 \mathrm{~cm}$ over a hundred-year period. The changes in rainfall may fluctuate from about $-30 \%$ to $+30 \%$. This change will reduce crop yield and become prone to drought in many areas so that cultivation of some crops such as rubber, oil palm, and cocoa will not be possible (NRS 2001). The projection shows that the maximum monthly precipitation will increase up to $51 \%$ over Pahang, Kelantan and Terengganu, while minimum precipitation will decrease between $32 \%$ to $61 \%$ for all over Peninsular Malaysia. Consequently, annual rainfall will increase up to $10 \%$ in Kelantan, Terengganu, Pahang and North West Coast, and decrease up to 5\% in Selangor and Johor (NAHRIM 2006). This variation of climate factors will cause the agricultural system to be vulnerable in Malaysia.

Moreover, the climatic factors affect, directly or indirectly, the social and economic sustainability of the farmers. Climate changes cause crop damages, low productivity and high production cost that leads to losses of farmers' income, poverty level increases, and seasonal 
unemployment rates increase (Siwar et al. 2009). This empirical study focuses the socioeconomic sustainability of the paddy farming community under current climatic change scenario in the perspective of Malaysia.

\section{Methodology}

To focus on the socioeconomic sustainability of the farmers under the rapid climatic changes in Malaysia, this article obtained partial data from a research project (Alam et al. 2010a) of Institute for Environment and Development (LESTARI), National University of Malaysia (UKM). The data are mostly based on the primary questionnaire survey on paddy producing farmers in the area of Integrated Agricultural Development Area (IADA), North-West Selangor, Malaysia. Among the total population size of 10,300, a sample of 198 respondents is considered for this study. These 198 households cover a total of 577.53 ha of paddy area. The number of sample is proportionately distributed among the eight areas based on the size of the irrigated land area. The sample within the area is selected randomly. The data have been analysed by using descriptive statistics, percentile and scale analysis, and cross sectional regression.

\section{Result and Discussion}

As the agricultural productivity varies due to climatic change, the income of the farmer also declines and as a consequence, poverty increases. Among the paddy producing farmers, $68.2 \%$ agree that paddy production is not very profitable due to low productivity, but $67.2 \%$ of the farmers say paddy production is still better than other crops production because of the huge subsidy and incentives for the paddy sector (Alam et al. 2011a). Due to decreases of income from agriculture, the poverty is still high in the agriculture dependent households (Alam et al. 2010b,c). Among the farming households, $2.1 \%$ of the population live below $\$ 1$ dollar poverty line, and $8.2 \%$ of the population live below $\$ 2$ dollar poverty line; based on Malaysia's poverty line, $3.5 \%$ of households or $3.7 \%$ of the population live below the poverty line. Outside of IADA area and without the subsidy, the poverty rate is higher than this. Moreover, the subsidy also needs to increase gradually matching the increasing effects of climatic changes to help the farmers cope with income losses; otherwise poverty rate will increase in future. Currently, the target of IADA is to ensure RM 2,000 monthly income only from paddy production for each farmer. If only one farmer in each household is considered, there are $44 \%$ of the households currently below this level. Thus, a huge increase in income is required to reach the level. Among the paddy farmers, a large number of households $(56.6 \%)$ have no savings, and $79.8 \%$ of the households have no savings except the savings of heads of the household. Therefore, any type of spike in regular life due to natural disaster, disease, crime or social issues can push them towards below poverty line, especially those who are marginally above the poverty line or dependent on loans.

The unexpected behaviour of climatic factors also causes many negative impacts on human health that affect more on the farming community. $73.7 \%$ farmers mention that they face several health problems due to climatic change. A wide range of diseases - vector-borne, water-borne, and respiratory- have links to climatic change. Climatic change is also directly connected to incidences of diarrhea, skin disease, malaria, kala-azar, dengue fever, and other illnesses. Other health related factors, such as dehydration, malnutrition, and heat stress, especially among elder farmers, are closely linked to climatic factors and food production.

When the profitability of agricultural production declines, educated people are less interested in agriculture because of low profitability compared to off-farm wage, but education level of the farmers has significant impacts on paddy yield (Alam et al. 2011b). A 1\% increase in 
primary level education of a farmer leads to $0.07 \%$ increase in paddy yield, and $1 \%$ increase in secondary level education of a farmer leads to $0.08 \%$ increase in paddy yield. The farmers identified in this study are mostly of old age group, because young people are not interested in agriculture and shift towards SME and industrial sectors. Therefore, the attention towards agriculture decreases and farming is treated as a secondary occupation instead of a main occupation. However, if the secondary occupations amongst farmers increase by $1 \%$, the yield of paddy production decreases by $0.02 \%$. Currently, $17.2 \%$ of the farmers are engaged in agriculture on a part-time basis. Many farmers are trying to reduce their involvement in agriculture from full-time engagement to part-time workers because $56.6 \%$ think full-time engagement in agriculture is less profitable than part-time engagement.

The household income of farmers is changing from agriculture to other sources such as, nonagricultural wage or salary, business income, spouse income, children income, pension, welfare, land rent, savings or investment return, interest, insurance etc, but the ratio of nonagriculture to agricultural income has significant negative impacts on paddy yield. If the ratio increases by $1 \%$, the yield of paddy productivity declines by $0.01 \%$. However, currently $41.4 \%$ of the farmers have incomes from outside of agricultural sources, a maximum of $97.7 \%$ for any individual case. On an average, $14.3 \%$ of the incomes of paddy farming households come from non-agricultural income.

The land ownership status of the farmers changes over time due to agricultural profitability decline. Due to climatic change, small farmers lose more and are interested to lease land to large farms, and the number of large farm increases due to the opportunity of economies of scale. Among several physical characteristics of the farm, technology and geographical position have significant impacts on paddy yield. $1 \%$ increase in the number of machineries leads to $0.06 \%$ increase in the productivity of the paddy. The geographical area also shows significant impacts on paddy production, such as Sg. Burong shows positive impacts on yield where the elasticity value is 0.02 . Thus, large farms take this opportunity of economics of scale and high productivity incentives from government. As a result, this leads to more income inequality among the farmers. Therefore, top $20 \%$ of the farmers receive $46.8 \%$ of the income and the bottom $20 \%$ receive only $5.6 \%$ of the income. The degree of inequality for Kuznets ratio is nearly three times (2.88) and the Gini coefficient is 0.443 indicating quite a high level of inequality in the agricultural community.

Government makes rules to produce a particular crop in a particular area but farmers' tendency increases to different crops due to the differences in profitability rates. The IADA area is allowed only for paddy production, but $41.9 \%$ of paddy producing farmers are engaged in livestock or other crops production, and one third of the farmers have incomes from permanent plants such as, mango, coconut, palm oil, cocoa, banana etc. It is alarming because the fields used for permanent trees are not possible to revert back for paddy. Farmers also like to produce seasonal crops, seasonal fruits, and seasonal vegetables. Farmers' choices depend on the income that is ultimately derived from profit margin changes among crops or final crops due to climatic change. As a result, expected areas of cultivation for a particular crop differ from actual cultivated areas. In some cases, farmers are not interested to cultivate land and as a result, total cultivated land also differs from cultivatable land. The average decrease of paddy land reported by the IADA authorities for the last three years was $0.34 \%$ (IADA 2009), and it is likely to decrease over the next seasons, because $7.1 \%$ of the farmers said that they are not willing to produce paddy in the next season. Among other socioeconomic particulars of farmers, the productivity of Malay farmers in terms of Chinese (race) shows statistically significant relationship where the elasticity is -0.4 . 
Currently, government provides a huge subsidy (input subsidy, price subsidy, paddy production incentives, Yield Increase Incentives, free irrigation infrastructures, and water supply) to promote and increase paddy production. Government subsidy for agricultural sector is increasing each year (Agriculture Statistical Handbook, 2008). The subsidies for urea and compound fertilizer have been continuing since 1979. The incentive for land preparation and organic fertilizer has been continuing since 2007. Providing compound and urea fertilizers and pesticide incentives was introduced in 2008 and is still continuing. In spite of these supports, still $12.1 \%$ of the farmers cannot cope with climatic changes with the current level of supports. Due to productivity decreases, farmers' dependency on external supports increases to maintain a certain level of regular income.

\section{Conclusion and Recommendations}

Overall, climatic change influences the agricultural sustainability negatively in Malaysia; as a consequence people who are dependent on agriculture are more vulnerable in terms of socioeconomic perspective than other social groups in Malaysia. Adaptation is very essential in the long run for agricultural and livelihood sustainability in Malaysia. Adaptation approaches need to be followed at an individual farmer level and policy level (Alam et al. 2010d, 2012b). Adaptation will be highly dependent on technology in the long-run, and financial protection in the short-run. Government bodies too need to offer preferable subsidy policies and ensure financial sustainability for the farmers.

\section{Acknowledgement}

We are thankful to Ministry of Science, Technology and Environment of the Government of Malaysia for generously funding the research, under the Research University Grants (UKMAP-PLW-04-2010, LRGS-TD-2011-UPM-UKM-KM-04 and UKM-GUP-PI-08-34-081). We would also like to thank Dr. Rafiqul Islam Molla (Multimedia University, Malaysia), Dr. Mohd Ekhwan bin Toriman (National University of Malaysia), and Md. Wahid Murad (University of Adelaide, Australia) for their advices and supports at various stages of the study.

\section{References}

Agriculture Statistical Handbook. (2008) Paddy, Ministry of Agriculture, Malaysia.

Alam M.M., Siwar C., and Al-Amin A.Q. (2010d) Climate Change Adaptation Policy Guidelines for Agricultural Sector in Malaysia. Asian Journal of Environmental and Disaster Management 2(4):463- 469. DOI 10.3850/S1793924011000873 Cited 05 Nov 2011

Alam M.M., Siwar C., Molla R.I., Toriman M.E., and Talib B. (2010c) Socioeconomic Impacts of Climatic Change on Paddy Cultivation: An Empirical Investigation in Malaysia. Journal of Knowledge Globalization 3(2):71-84. http://journals.sfu.ca/jkg/index.php/journal/article/view/57/44 Cited 05 Nov 2011

Alam M.M., Siwar C., Molla R.I., Toriman M.E., and Talib B. (2011a) Climate Change and Vulnerability of Paddy Cultivation in North-West Selangor, Malaysia: A Survey of Farmers' Assessment. Voice of Academia 6(1):45-56.

Alam M.M., Siwar C., Murad M.W., Molla R.I., and Toriman M.E. (2010b) Socioeconomic Profile of Farmer in Malaysia: Study on Integrated Agricultural Development Area in North-West Selangor. Agricultural Economics and Rural Development 7(2):249-26. ftp://www.ipe.ro/RePEc/iag/iag_pdf/AERD1013_249-265.pdf Cited 05 Nov 2011 
Alam M.M., Siwar C., Talib B., and Toriman M.E. (2011b) An Empirical Study on the Relationships between the Socioeconomic Profile of Farmers and Paddy Productivity in North-West Selangor, Malaysia. Asia-Pacific Development Journal 18(1). http://www.unescap.org/pdd/publications/apdj-18-1/5-Alam-and-others.pdf Cited 05 Nov 2011

Alam, M.M., Siwar, C. \& Toriman, M.E. (2010a) Socioeconomic Study of Climate Change: An Assessment of Agriculture and Livelihood Sustainability on Paddy Farming in Malaysia. LAP Lambert Academic Publishing: Saarbrucken.

Alam, M.M., Siwar, C., Talib, B., Mokhtar, M., and Mohd Ekhwan, T. 2012b. Climate Change Adaptation Policy in Malaysia: Issues for Agricultural Sector, African Journal of Agricultural Research 7(9): 1368-1373. http://www.academicjournals.org/ajar/PDF/pdf2012/5\%20Mar/Alam\%20et\%20al.pdf Cited 05 Nov 2012

IADA (Integrated Agricultural Development Area). (2009) Internal Unpublished Data from the record of North West Selangor, Malaysia, March.

NAHRIM. (2006) Final Report: Study of the Impact of Climate Change on the hydrologic Regime and Water Resources of Peninsular Malaysia, National Hydraulic Research Institute of Malaysia (NAHRIM) and California Hydrologic Research Laboratory (CHRL), Malaysia. (online) http://www.nahrim.gov.my/download/pksa/RegHCM_PM_Report_9_21_06_Ex\%20v 1.pdf Cited 05 Nov 2011

NRS. (2001) National Response Strategies to Climate Change. Ministry of Science, Technology and the Environment, Malaysia. (online) http://gedung.nahrim.gov.my/wapi/mctweb.dll/getObject?MID=WATER\%20RESOU RCES\&Sn=2038 Cited 05 Nov 2011

Siwar C., Alam M.M., Murad M.W., and Al-amin A.Q. (2009) A review of the linkages between climate change, agricultural sustainability and poverty in Malaysia. International Review of Business Research Papers 5(6):309-321. http://www.bizresearchpapers.com/23.\%20Siwar.pdf. Cited 05 Aug 2011 